\title{
Efektivitas Penggunaan Google classroom dan Zoom Cloud Meeting Terhadap Minat Belajar IPS
}

\author{
Ana Ari Susanti ${ }^{1}$, Firosalia Kristin ${ }^{2}$ \\ 1,2 Program Studi Pendidikan Guru Sekolah Dasar, Universitas Kristen Satya Wacana, Salatiga, Indonesia
}

\section{ART I CLE IN F O}

Article history:

Received September 23, 2021

Revised September 15, 2021

Accepted October 03, 2021

Available online October 25, 2021

Kata Kunci:

Google Classroom, Zoom,

Minat Belajar

Keywords:

Google Classroom, Zoom,

Interest to Learn

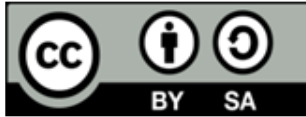

This is an open access article under the CC BY-SA license.

Copyright $(2021$ by Author. Published by Universitas Pendidikan Ganesha.

\begin{abstract}
A B S T R A K
Penelitian ini bertujuan untuk menganalisis Keefektifan Penggunaan Google classroom Dan Zoom Cloud Meeting Terhadap Minat Belajar IPS Siswa Kelas V SD. Jenis penelitian ini adalah eksperimen semu(Quasi Experimental Research). Penulis mengawali penelitian dengan memberikan soal tes, dan angket guna memudahkan penulis untuk mengumpulkan data. Subjek dalam penelitian ini adalah 40 siswa dari kelas google classroom yang berjumlah 20 siswa dan 20 siswa dari kelas Zoom. yang diambil dengan menggunakan teknik probability sampling jenis cluster sampling. Metode pengumpulan data melalui tes dan angket. Dalam menganalisis data dilakukan menggunakan metode analisis data statistik deskriptif kuantitatif uji prasyarat, uji T. Hasil pengujian hipotesis, dengan uji t-sig (2-tailed) diperoleh 0,000 $<0,05$ dengan $\mathrm{t}_{\text {hitung }} 4,812>\mathrm{t}_{\text {tabel }} 2,021$ maka $H_{O}$ ditolak yang berarti ada perbedaan minat belajar IPS. Hal tersebut dapat dibuktikan dengan meningkatnya minat belajar siswa kelas V SD denganmenggunakan google classroom dengan hasildata pretest dan diperoleh hasil 62.00 meningkatmenjadi 76.00, sedangkan zoom cloud meeting terdapat hasil pretest55,00 dan posttest 67,5 . Oleh karena itu dapat disimpulkan bahwa e-learning berbasis Google classroom lebih efektif terhadap minat belajar IPS siswa dibandingkan dengan e- learning berbasis Zoom Cloud Meeting.implikasi dalam penelitian ini adalah dapat mengembangkan minat belajar IPS dalam proses pembelajarandan dapat meningkatkan hasil belajar IPS siswa melalui google classroom.
\end{abstract}

\section{A B S T R A C T}

This study aims to analyze the effectiveness of the use of Google classroom and Zoom Cloud Meetings on the Social Studies Learning Interest of Grade V Elementary School Students. This type of research is a quasi-experimental (Quasi Experimental Research). The author started the research by giving test questions, and questionnaires to make it easier for the author to collect data. The subjects in this study were 40 students from the Google classroom class who collected 20 self-employed and 20 Zoom class students. taken by using probability sampling technique cluster sampling type. The method of collecting data is through tests and questionnaires. In analyzing the data, it was carried out using descriptive quantitative data analysis method prerequisite test, $T$ test. The results of hypothesis testing, with the $t$-sig (2-tailed) test obtained 0.000 $<0.05$ with $t$. count $4.812>t_{-}$(table) 2.021 then $\mathrm{H}_{-} \mathrm{O}$ rejected means there is differences in social studies learning interest. This can be proven by zooming in on the interest in learning of fifth grade elementary school students using google classroom with the results of the pretest data and the results obtained from 62.00 increasing to 76.00 , in the cloud meeting there are pretest results of 55.00 and posttest 67.5. Therefore, it can be said that e-learning based on Google classroom is more effective towards interest in learning social studies compared to e-learning based on Zoom Cloud Meeting. learning in this research is to be able to develop interest in social studies learning in the learning process and can improve student social studies learning outcomes through google classroom.

\section{PENDAHULUAN}

Pembelajaran adalah proses yang sangat penting guna memperoleh pengalaman yang nantinya digunakan oleh siswa dalam kehidupanya sehari-hari. pembelajaran yang memberikan pengalaman kepada siswa haruslah pengalaman yang memberikan kesempatan kepada siswa untuk berinteraksi dengan seumber belajar dan teman sebaya serta aktif dalam membanguan pengetahuannya sendiri. dengan kata lain partisipasi siswa dalam proses pembelajaran akan mempengaruhi keberlangsungan proses pembelajaran dan seberapa 
besar pengalaman yang diperolehnya (Jupriyanto, 2018). Pembelajaran yang memberikan kesempatan kepada siswa untuk belajar lebih aktif merupakan pembelajaran yang bermakna, pembelajaran bermakna akan memberikan pengalaman yang bisa digunakan siswa dalam kehidupan sehari-hari serta dapat mengembangkan kemampuan social emosiaonal siswa (Bressington et al., 2018; Kostiainen et al., 2018). Pembelajaran yang berkulitas sangat mempengaruhi hasil belajar siswa. Salah satu pembelajaran yang penting diberikan di sekolah dasar adalah IPS. Pembelajaran IPS akan memberikan kesempatan kepada siswa untuk membangun hubungan social dan membangun interaksi siswa. IPS merupakan suatu pendekatan interdisipliner dari ilmu social, dalam pembelajaran IPS mengkaji peristiwaa, konsep dan gerenarilasi yang berkaitan dengan isu social (A \& Amran, 2017). Pelajaran IPS merupakan integrasi dari ilmu-ilmu sosial dan kemanusiaan(Anggriani \& Ishartiwi, 2018). IPS merupakan ilmu yang mempelajari gejala-gejala alam dan tingkah laku manusia (Wardani et al., 2019). Jadi, jabaran-jabaran tesebut memberikan gambaran pentingnya pembelajan IPS dalam kehidupan sehari-hari.

Pentingnya pembelajaran IPS menuntut proses pembelajaran yang dilakukan lebih banyak siswa aktif dalam proses pembelajaran. karena dengan siswa aktif dalam proses pembelajaran akan memberikan dampak terhadap minat belajar siswa. Minat memegang peranan yang sangat penting dalam kehidupan siswa dan berdampak besar pada sikap dan perilaku. Siswa yang tertarik pada kegiatan belajar akan berusaha lebih keras daripada siswa yang kurang tertarik untuk belajar (Aprijal et al., 2020; Nurfadilla \& Rosleny, 2018). Dengan kata lain minat belajar merupakan faktor pendorong siswa untuk belajar karena adanya minat akan menumbuhkan kesenangan dan kemauan siswa untuk belajar (Yunitasari \& Hanifah, 2020). Minat belajar mempengaruhi kualitas belajar siswa, minat belajar sebagai sebuah produk dan persepsi efikasi diri yang akan mempengaruhi motivasi siswa dalam proses belajar (Tamardiyah, 2017). Siswa dengan minat belajar yang tinggi pada akhirnya akan mencapai hasil belajar yang lebih baik daripada siswa dengan minat belajar yang rendah(Chen et al., 2020; Sirajuddin, 2018; Sulistyawati, 2020). Siswa yang tidak berminat terhadap bahan pelajaran akan menunjukan sikap kurang simpatik, malas dan tidak bergairah (Lisma et al., 2019). Pentingnya minat belajar dalm proses pembelajaran menuntut pembelajaran mempunyai suasana menarik yang mampu memberikan stimulus yang memicu minat belajar siswa (Nasution et al., 2020). Jadi untuk menciptakan minat belajar siswa diperlukan pembelajaran yang sesaui dengan kondisi siswa.

Namun, dilapangan menunjukkan berbeda, pembelajaran masih menggunakan metode konvensioanl (ceramah) dan group WA akibatnya siswa merasa bosan selama pembelajaran berlangsung. Pembelajaran yang tidak sesuai dengan karakteritik siswa akan membuat siswa kurang tertarik dan merasa bosan dalam melakukan pembelajaran yang dibawakan oleh guru. Dibuktikan dengan anak yang tidak mau menirukan instruksi, bermain sendiri, bermain dengan teman dan berbicara sendiri (Ayuningtyas \& Wijayaningsih, 2020). Siswa akan kehilangan minat belajar jika proses pembelajaran tidak dikemas menarik apalagi pembelajaran yang dianggap sulit (Yuliar, 2019). Pembelajaran yang dilakukan selalu bersifat individu dan kurang memberikan kesempatan siswa untuk belajar sambil bermain sehingga minat belajar siswa rendah dan hasil belajar siswa juga masih banyak di bawah KKM (Listyarini et al., 2018). Prestasi siswa rendah diakibatakan rendahnya minat sisiwa dalam proses pembelajaran (Khodijah \& Setiawan, 2020). Jadi, rendahnya minat siswa dalam proses pembelajaran akan berpengaruh terhadap hasil belajar. pernyataan ini sesaui dengan penelitian yang menyatakan bahwa terdapat hubungan minat mahasiswa dengan prestasi belajar mahasiswa secara signifikan (Pambudi, 2018). Penelitian yang menyatakan bahwa terdapat hubungan positif antara minat dan hasil belajar (Ardiansah, 2019; Handayani et al., 2020). Penelitian yang menyatakan bahwa terdapat hubungan yang signifikan antara minat belajar dengan hasil belajar (Rofiqah \& Sunaini, 2017). Penelitian yang menyatakan bahwa minat belajar memepngaruhi hasil belajar (Rozikin et al., 2018). Jabaran tersebut memerikan gamabaran bagaiman minat belajar dan hasil belajar adalah dua hal yang saling berhubungan. Oleh sebab itulah jika minat belajar siswa rendah maka hasil belajar juga rendah. Jika hal ini dibiarkan tentunya akan berdampak sangat buruk terhadap kualitas pembelajaran. oleh sebab itulah harus dicarikan solusi yang sesaui dengan situasi pembelajaran daring.

Salah satu solusi yang ditawarkan dalam meningkatkan minat belajar siswa selama proses pembelajaran daring ini adalah, pembelajaran dengan google classroom. Google classroom memungkinkan kegiatan belajarmengajar yang lebih produktif dan bermakna dengan menyederhanakan tugas, meningkatkan kolaborasi, dan memfasilitasi komunikasi (Atikah et al., 2021). Google classroom merupakan salah satu aplikasi virtual class yang sederhana, dan penggunaannya mudah dipahami hanya dengan memasukkan akun email masing-masing dan media dapat diakses dimana saja serta kapan saja selama terhubung di internet (Fitriani et al., 2019; Rut et al., 2020). Lain itu google classroom termasuk dalam platform Learning Management System (LMS) layanan berbasis internet dan disediakan oleh google sebagai sistem e- learning yang meringankan pendidik dalam pengarsipam dan pengorganisasian berkas tugas serta proses penilaian (Atikah et al., 2021; Soni et al., 2018). Aplikasi google classroom digunakan dengan cara pendidik mengirim file bahan ajar baik berupa narasai, word, power point atau video yang sekaligus dapat didownload dalam bentuk sphread sheet yang berupa file excel, dokumen yang tersimpan secara langsung selama pelaksanaan pembelajaran. Dengan aplikasi google classroom ini bisa memudahkan guru serta siswa dalam melaksanakan proses belajar dengan lebih mendalam. Aplikasi Google classroom dapat digunakan oleh siapa saja yang bergabung dengan kelas tersebut. Penggunaan Google classroom 
terdapat beberapa fitur, misalnya pembagian informasi, materi, berdiskusi, mengumpulkan tugas, dan dapat menilai tugas yang sudah dikumpulkan oleh peserta didik. selain itu Google classroomterdapat cara yang mudah digunakan, menghemat waktu dan berbasis cloud serta dalam penggunaanya gratis (Maharani \& Kartini, 2019).

Penggunaan google classroom mampu membuat proses pembelajaran mengajar menjadi lebih efektif dan praktis (Karollina, N., Hidayati, U., \& Syaflita, 2021; Permata \& Bhakti, 2020; Qholby \& Lazulva, 2020). Pernyataan ini sesaui dengan hasil penelitian yang menyatakan bahwa terdapat pengaruh signifikan media pembelajaran google classroom terhadap motivasi belajar mahasiswa (Nirfayanti \& Nurbaeti, 2019). Penelitian yang menyatakan bahwa perbedaan hasil belajar matematika peserta didik antara pembelajaran e-learning berbantuan aplikasi Zoom dan Google classroom (Fiyanti et al., 2020). Penelitian yang menyatakan pembelajaran berbasis riset dengan memanfaatkan google classroom efektif meningkatkan minat dan hasil belajar mahasiswa (Zahrawati \& Aras, 2020). Penelitian yang menyatakan bahwa google classroom memiliki efektivitas untuk menunjang keterampilan pemecahan masalah dari (Maharani \& Kartini, 2019). Penelitian yang meneytakan bahwa model Project Based Learning berbantu media google classroom memberikan hasil belajar yang lebih baik dibandingkan model Project Based Learning yang tidak menggunakan media google classroom (Qholby \& Lazulva, 2020). Penelitian yang menyatakan bahwa siswa puas dengan adanya media google classroom digunakan untuk membatu proses pembelajaran (Essgaer \& Nasir, 2021). Jadi, adanya media google classroom sangat membatu proses pembelajaran daring saat ini. Selain media google classroom dalam pembelajaran daring juga zoom cloud meeting.

Zoom Meeting merupakan sebuah media pembelajaran menggunakan video (B. et al., 2021). Aplikasi konferensi zoom ini memungkinkan untuk berkomunikasi langsung dengan siapa pun melalui video. Aplikasi ini menggabungkan konferensi video, konferensi online, obrolan, dan kolaborasi seluler untuk menyediakan layanan konferensi jarak jauh. Aplikasi ini banyak digunakan sebagai media komunikasi jarak jauh (Haqien \& Rahman, 2020; Ismawati \& Prasetyo, 2020). Penggunaan Zoom Meeting akan menjaga keamanan rekaman (Brahma, 2020). Adanya zoom cloud meeting sebagai media pembelajaran sangat membantu proses pembelajaran dengan saat pembelajaran daring. Beberpa penelitian menyatakan bahwa melalui zoom, proses pembelajaran dapat melakukan video konferensi yang dijadikan sarana berkomunikasi dalam pembelajaran secara online (Brahma, 2020). Penelitian yang menyatakan bahwa pelaksaan pembelajaran dnegan media Zoom Cloud Meeting bersifat fleksibilitas, meningkatkan kedisiplinan, dan beberapa fitur tambahan yang dapat menunjang kelancaran pelaksanaan pembelajaran (Mubarak et al., 2020). Penelitian yang menyatakan bahwa pembelajaran dengan video conference efektif, interkatif, dapat mendukung pembelajaran jarak jauh, memudahkan anak didik untuk menyerap materi pembelajaran yang disampaikan pendidik karena lebih real time (Ismawati \& Prasetyo, 2020). Berdasarkan jabaran tersebut penelitian yang bertujuan untuk menganalisis Keefektifan Penggunaan Google classroom Dan Zoom Cloud Meeting Terhadap Minat Belajar IPS Siswa Kelas V SD dilakukan. Penelitian ini dilakukan dengan alasan masih minim penerapan media Google classroom Dan Zoom Cloud di sekolah dasar. Media Google classroom Dan Zoom Cloud lebih banyak diagunkan diperguruan tinggi. Mengetahui efektivitas Google classroom Dan Zoom Cloud dalam proses pembelajaran akan memberikan alternative dalam penggunaan media pembelajaran yang digunakan dalam pembelajarn daring.

\section{METODE}

Jenis penelitian ini adalah penelitian eksperimen semu (Quasi Experimental Research)dengan adanya kelas eksperimen dan kelas kontrol. Desain penelitian yang digunakan adalah penelitian eksperimen semu dengan nonequivalent control group design yang diawali dengan memberikan pretest terlebih dahulu, perlakuan dengan google classroom yang diberikan kepada kelas eksperimen dan zoom cloud meeting yang diberikan pada kelas kontrol. Kemudian, diberikan posttest dan angket yang digunakan untuk mengetahui perbedaan minat belajar IPS antara menggunakan googleclassroom dan zoom cloud meeting. Adapun gambaran mengenai desain penelitian nonequivalent control group design di gambarakan pada gambar 1.

\begin{tabular}{lll}
01 & $\mathrm{X} 1$ & 02 \\
03 & $\mathrm{X} 2$ & 04 \\
\hline
\end{tabular}

Gambar 1. Desain penelitian nonequivalent control group design (Sugiyono, 2011)

Subjek penelitian ini adalah siswa kelas V gdengan jumlah siswa 40 yaitu 20 siswa dari kelas eksperimen (google classroom) dan 20 siswa dari kelas kontrol (zoom cloud meeting). Pada saat ujicoba instrumen angket dilakukan dengan jumlah 20 siswa yang dimulai pukul 08.00-09.30 yang diawali dengan menyampaikan tujuan kedatangan peneliti, kemudian peneliti bertanya mengenai aktivitas dalam pembelajaran siswa ketika terdapat mata pelajaran IPS. Pada pelaksanaan penelitian yang peneliti awali dengan menjelaskan materi dan memberikan soal pretest terkait dengan mata pelajaran IPS terdapat sebagian siswa yang tidak semangat, hal tersebut dikarenakan siswa sudah merasakan bosan dengan pembelajaran yang hanya dengan 
metode konvensional (ceramah) baik pembelajaran tatap muka maupun daring. Namun, setelah siswa diperkenalkan dengan aplikasi e-learning google classroom, siswa terlihat antusias dan aktif. Google classroom dapat membantu guru dan membangun kelas virtual dengan pembelajaran dikelas yang artinya pemabgian kelas nyata di sekolah, dimana kelas-kelas yang termasuk dalam tugas, kuis serta tugas disetiap akhir pelajaran. Sedangkan pembelajaran online, interaksi didalam kelas dilakukan seperti dikelas konvensional dengan menggunakan google classroom, dimana setiap siswa dapat dengan bebas berkomunikasi dengan guru maupun teman sekelas.Metode pengumpulan data yang digunakan pada penelitian ini adalah tes dan angket melalui soal pilihan ganda dan instrumen angket. Adapun kisi-kisi instrumen dari google classroom dan zoom cloud meeting ditunjukkan pada table 1. Teknik analisis data yang digunakan adalah teknik analisis data statistik deskriptif kuantitatif sebagai uji prasyarat terdapat uji normalitas, homogenitas. Uji prasyarat dilakukan sebelum melakukan uji t yang berfungsi untuk mengatahui ada atau tidaknya perbedaan rata-rata antara kedua kelompok baik kelompok eksperimen maupun kelompok kontrol. Teknik analisis data dilakukan dengan bantuan SPPS.

Tabel 1. Kisi-Kisi Instrumen Minat belajar

\begin{tabular}{|c|c|c|c|c|}
\hline No & Dimensi & Indikator & No Item & Jumlah Item \\
\hline \multirow[t]{2}{*}{1.} & Kesukaan & - Gairah & $1, \underline{6}$ & 2 \\
\hline & & - Inisiatif & $2, \underline{4}$ & 2 \\
\hline \multirow[t]{2}{*}{2.} & Ketertarikan & - $\quad$ Partipasi & $\underline{7}, 10,11$ & 3 \\
\hline & & - Respnsif & $12, \underline{14}$ & 2 \\
\hline \multirow[t]{2}{*}{3.} & Perhatian & - Ketelitian & $3, \underline{5}, 15$ & 3 \\
\hline & & - Konsentrasi & $\underline{16}, 17$ & 2 \\
\hline \multirow[t]{3}{*}{4.} & Keterlihatan & - Kemauan & $13, \underline{9}$ & 2 \\
\hline & & - Keuletan & $\underline{18}, 19$ & 2 \\
\hline & & - Kerja keras & $\underline{8}, 20$ & 2 \\
\hline
\end{tabular}

\section{HASIL DAN PEMBAHASAN}

Hasil

Penelitian yang bertujuan untuk menganalisis kefektifan penggunaan google classrom dan zoom cloud meeting terhadap minat belajar IPS siswa V SD Negeri 1 Negeri dilakukan melalui tes dan angket. Penelitian ini membandingkan google classroom dan zoom cloud meeting. Analisis deskriptif disajikan dengan tabel deskriptif statistik yaitu normalitas, homogenitas dan hipotesisberupa data minat belajar dan hasil belajar sebelum diberikan perlakuan (pretest) guna mengukur minat belajar IPS pada siswa. Setelah itu diperoleh hasil minat belajar setelah mendapatkan perlakuan (posttest dan angket). Berdasarkan hasil uji normalitas minat belajar dari kedua kelompok baik kelompok eksperimen maupun kelompok kontrol didapatkan bahwa data berdistribusi normal dengan nilai signifikansi $>0,05$. Tingkat signifikansi nilai minat kelompok eksperimen dengan google classroom adalah 0,200 > 0,05 yang artinya berdistribusi normal. Tingkat singnifikansi nila minat kelompok kontrol dengan zoom cloud meeting adalah 0,006 berdistribusi normal. Hasil uji homogenitas minat belajar diketahui bahwa nilai signifikansi pada kolom levene's adalah 0.155 dimana $>0,05$ yang berarti bahwa kedua kelompok terdapat varian yang sama atau dikatakan homogen. Hasil analisis Independent Sample T-test. hasil analisis uji t untuk data minat beralajar siswa sebelum dibri perlakukan diperolah bahwa tidak ada perbedaan minat belajar siswa kelompok eksperiment dan kelasa kontral hal ini dapat dilihat dari nilai sig. yang lebih besar dari 0,05 yaitu 0,106. Setelah dilakuakn perlakuan hasil analisis Independent Sample T-test menunjukkan terdapat perbedaan antar kelas eksperimen dan kelas control. Ini dapat dilihat dari niali sig< 0,05 yaitu 0,015. Ini berarti terdapat berbedaan antara siswa yang dibelajarkan dengan media google classroom dan zoom cloud meeting. Hasil ini didukung dengan hasil perhitungan analisis analisis deskriptif. Hasil analisis diperoleh rata-rata minat belajar dari kelas eksperimen sebesar 64, 40, dan kelas kontrol 61,30. Kemudian, berdasarkan nilai rerata minat belajar, dan nilai rerata pretest dan postest terdapat peningkatan terhadap minat belajar IPS menggunakan Google classroompada kelompok eksperimen sebesar 16,1; sedangkan kelompok kontrol 15.3. Data yang terdapat pada diagram adalah hasil instrumen angket yang telah diberikan kepada siswa kelas eksperimen dengan rata-rata jumlah skor 64,4 dan nilai 80,5, sedangkan kelas kontrol dengan rata-rata jumlah skor61,3 dan nilai 76,6.

Hasil penelitian menyatakan bahwa pemakaian google classroom lebih efektif terhadap minat belajar IPS siswa kelas V SD Negeri Sedadi dibandingkan dengan penggunaan zoom cloud meeting. Perbedaan hasil minat belajar antara kelas eksperimen dan kelas kontrol terjadi karena pembelajaran dikelas eksperimen menggunakan google classrom, sedangkan kelas kontrol dengan zoom cloud meeting. Proses pembelajaran menggunakan google classroom siswa dapat mengoperasikan dengan lebih mudah, materi dapat dibaca kapan saja dan tampilan yang sederhana, serta dapat memberi informasi berkaitan dengan pembelajaran, dan dapat mengumpulkan tugas pada platform tersebut, sehingga dapat meningkatkan ketertarikan siswa untuk belajar 
menggunakan google classroom. Platform Google classroom merupakan aplikasi yang mudah dimengerti dan dipahami serta mudah digunakan terutama untuk guru yang menyangka dirinya terletak diluar basis pengetahuan teknologi yang berkembang. Google classroom ialah suatu layanan berbasis internet yang disediakan oleh google sebagai sistem e-learning berbasis virtual class untuk pembelajaran jarak jauh, dengan memakai alat elektronik seperti komputer, keefektifan e-learning dan google classroom terdiri dari aspek perancangan dan pembuatan materi, aspek penyampaian materi serta aspek interaksi (Nurfalah, 2019). Pemakaian Google classroom sebagai media belajar daring disekolah dasar, bisa memudahkan pendidik dalam mempersiapkan kelas belajar, pengumpulan tugas, menghemat waktu dan terjalinnya komunikasi dengan baik, serta tidak membutuhkan dana yang banyak. Google classroom atau ruang kelas google ialah suatu pembelajaran campuran sebagai ruang pendidikan yang mampu memudahkan pendidik dalam membagikan dan menggolongkan setiap penugasan secara simple tanpa kertas, sehingga bisa mempermudahkan guru dan siswa dalam mengorganisir bahan ajar serta tugas yang telah diberikan dan melakukan diskusi pada materi yang belajar yang dapat dilakukan kapanpun dan dimanapun (Mayasari et al., 2019). Google classroom adalah alat yang efektif untuk pengajaran dan pembelajaran online karena kemudahan penggunaan dan fitur yang ramah siswa dan ramah guru serta mensitribusikan materi, mendistribusikan tugas, membuat ujian dapat terintegrasi langsung dengan sistem penilaian (Sheelavant, 2020; Sutrisna, 2018). Penggunaan Google classroom terdapat beberapa fitur, misalnya pembagian informasi, materi, berdiskusi, mengumpulkan tugas, dan dapat menilai tugas yang sudah dikumpulkan oleh peserta didik. selain itu Google classroomterdapat cara yang mudah digunakan, menghemat waktu dan berbasis cloud serta dalam penggunaanya gratis (Maharani \& Kartini, 2019). Jadi, dengan fiktur yang berbeda akan membuat suasana pembelajaran lebih menarik dan akan menimbulkan minat belajar siswa dan kelebihan yang lain ada penggunaannya sangat sederhana sehingga tidak membuat siswa frustasi dalam menggunakannya. Suasan seperti ini tentunya dapat meningkatkan minat siswa dalam proses pembelajaran secara daring.

Minat memegang peranan yang sangat penting dalam kehidupan siswa dan berdampak besar pada sikap dan perilaku. Siswa yang tertarik pada kegiatan belajar akan berusaha lebih keras daripada siswa yang kurang tertarik untuk belajar (Aprijal et al., 2020; Nurfadilla \& Rosleny, 2018). Dengan kata lain minat belajar merupakan faktor pendorong siswa untuk belajar karena adanya minat akan menumbuhkan kesenangan dan kemauan siswa untuk belajar (Yunitasari \& Hanifah, 2020). Minat belajar mempengaruhi kualitas belajar siswa, minat belajar sebagai sebuah produk dan persepsi efikasi diri yang akan mempengaruhi motivasi siswa dalam proses belajar (Tamardiyah, 2017). Siswa dengan minat belajar yang tinggi pada akhirnya akan mencapai hasil belajar yang lebih baik daripada siswa dengan minat belajar yang rendah (Chen et al., 2020; Sirajuddin, 2018; Sulistyawati, 2020). Siswa yang tidak berminat terhadap bahan pelajaran akan menunjukan sikap kurang simpatik, malas dan tidak bergairah (Lisma et al., 2019). Pentingnya minat belajar dalm proses pembelajaran menuntut pembelajaran mempunyai suasana menarik yang mampu memberikan stimulus yang memicu minat belajar siswa (Nasution et al., 2020). Jadi untuk menciptakan minat belajar siswa diperlukan pembelajaran yang sesuai dengan kondisi siswa. Pembelajaran google classroom sesuai dengan kondisi siswa saat ini dimana siswa tidak dituntun mengusai teknologi yang membuat Frustasi.

Hasil penelitian ini didukung hasil penelitian yang menyatakan bahwa hasil penelitian yang menyatakan bahwa terdapat pengaruh signifikan media pembelajaran google classroom terhadap motivasi belajar mahasiswa (Nirfayanti \& Nurbaeti, 2019). Penelitian yang menyatakan bahwa perbedaan hasil belajar matematika peserta didik antara pembelajaran e-learning berbantuan aplikasi Zoom dan Google classroom (Fiyanti et al., 2020). Penelitian yang menyatakan pembelajaran berbasis riset dengan memanfaatkan google classroom efektif meningkatkan minat dan hasil belajar mahasiswa (Zahrawati \& Aras, 2020). Penelitian yang menyatakan bahwa google classroom memiliki efektivitas untuk menunjang keterampilan pemecahan masalah dari (Maharani \& Kartini, 2019). Penelitian yang meneytakan bahwa model Project Based Learning berbantu media google classroom memberikan hasil belajar yang lebih baik dibandingkan model Project Based Learning yang tidak menggunakan media google classroom (Qholby \& Lazulva, 2020). Penelitian yang menyatakan bahwa siswa puas dengan adanya media google classroom digunakan untuk membatu proses pembelajaran (Essgaer \& Nasir, 2021). Jadi, adanya media google classroom sangat membatu proses pembelajaran daring saat ini.

Temuan yang lain dalam penelitian ini adalah pembelajaran dengan Zoom Cloud Meeting adalah salah satu solusi yang bisa digunakan dalam proses pembelajaran. Zoom Meeting merupakan sebuah media pembelajaran menggunakan video (B. et al., 2021). Aplikasi konferensi zoom ini memungkinkan untuk berkomunikasi langsung dengan siapa pun melalui video. Aplikasi ini menggabungkan konferensi video, konferensi online, obrolan, dan kolaborasi seluler untuk menyediakan layanan konferensi jarak jauh. Aplikasi ini banyak digunakan sebagai media komunikasi jarak jauh (Haqien \& Rahman, 2020; Ismawati \& Prasetyo, 2020). Penggunaan Zoom Meeting akan menjaga keamanan rekaman (Brahma, 2020). Adanya zoom cloud meeting sebagai media pembelajaran sangat membantu proses pembelajaran dengan saat pembelajaran daring. Beberpa penelitian menyatakan bahwa melalui zoom, proses pembelajaran dapat melakukan video konferensi yang dijadikan sarana berkomunikasi dalam pembelajaran secara online (Brahma, 2020). Penelitian yang menyatakan bahwa pelaksaan pembelajaran dengan media Zoom Cloud Meeting bersifat fleksibilitas, meningkatkan 
kedisiplinan, dan beberapa fitur tambahan yang dapat menunjang kelancaran pelaksanaan pembelajaran (Mubarak et al., 2020). Penelitian yang menyatakan bahwa pembelajaran dengan video conference efektif, interkatif, dapat mendukung pembelajaran jarak jauh, memudahkan anak didik untuk menyerap materi pembelajaran yang disampaikan pendidik karena lebih real time (Ismawati \& Prasetyo, 2020). Jadi, Zoom Cloud Meeting akan membatu proses pembelajaran tanpa harus bertemu secara tatap muka. Berdaarakan hasil penelitian media Zoom Cloud Meeting dalam proses pembelajaran kurang efektif digunakan dalam proses pembelajaran khususnya untuk meningkatkan minat belajar siswa. hal ini tidak terlepas dari keterbatasan yang dimiliki oleh siswa baik kemampuan maupun fasilitas. Hal ini mengingat Zoom Cloud Meeting memerlukan fasilitas yang lebih kompleks dibandingkan dengan media google classroom. serta keterbatasannya dalam mengeimkan materi media google classroom bisa menyimpan materi yang bisa mmebuat siswa dapat membaca kaapanpun materi yang diinginkan sedangkan Zoom Cloud Meeting materi hanya bisa diakses saat itu, dan jika siswa yang etrbatas pada jumlah kouta internet dan kurang stabilnya signal akan membuat pembelajaran dengan Zoom Cloud Meeting terganggu. Berdarkan jabaran tersebut penggunaan media google classroom lebih efektif dibadingkan Zoom Cloud Meetin

\section{SIMPULAN}

Proses pmbelajaran dengan penggunaan Google classroom yang telah dilakukan dapat menjadikan pembelajaran lebih efektif, dan dapat menambah pengetahuan siswa tentang penggunaan google classrom, selain itu diperoleh hasil bahwa siswa sangat berminat dengan google classrom pada saat belajar IPS dibandingkan dengan Zoom Cloud Meeting,melalui penilitian ini dalam melaksanakan proses pembelajaran, guru dapat menggunakan Google classroomdalam pembelajaran daring maupun tatap muka disekolah untuk meningkatkan minat belajar IPS siswa.

\section{DAFTAR PUSTAKA}

A, N., \& Amran, M. (2017). Penerapan Model Pembelajaran Kooperatif Tipe Snowball Throwing Untuk Meningkatkan Hasil Belajar Siswa Pada Mata Pelajaran Ips Kelas V Sdn Mapala Kota Makassar. JIKAP PGSD: Jurnal Ilmiah Ilmu Kependidikan, 1(1), 11. https://doi.org/10.26858/jkp.v1i1.5041.

Anggriani, R., \& Ishartiwi, I. (2018). Keefektifan metode role playing terhadap keaktifan dan kerja sama siswa dalam pembelajaran IPS. Harmoni Sosial: Jurnal Pendidikan IPS, 4(2), 212-221. https://doi.org/10.21831/hsjpi.v4i2.11017.

Aprijal, A., Alfian, A., \& Syarifudin, S. (2020). Pengaruh Minat Belajar Siswa Terhadap Hasil Belajar Siswa di Madrasah Ibtidaiyah Darussalam Sungai Salak Kecamatan Tempuling. MITRA PGMI: Jurnal Kependidikan MI, 6(1), 76-91. https://doi.org/10.46963/mpgmi.v6i1.125.

Ardiansah, F. (2019). Pengaruh Penggunaan Media Video Terhadap Minat dan Hasil Belajar Siswa Kelas XI pada Pelajaran PAI DI Sma YPI Tunas Bangsa Palembang. JKTP Jurnal Kajian Teknologi Pendidikan, 2(1), 5670. https://doi.org/10.17977/um038v2i12019p001.

Atikah, R.-, Prihatin, R. T., Hernayati, H., \& Misbah, J. (2021). Pemanfaatan Google Classroom Sebagai Media Pembelajaran Di Masa Pandemi Covid-19. Jurnal Petik, 7(1), 7-18. https://doi.org/10.31980/jpetik.v7i1.988.

Ayuningtyas, T. Y., \& Wijayaningsih, L. (2020). Efektivitas Permainan Detumbar (Dengarkan, Temukan gambar) terhadap Minat Belajar Anak Usia Dini. Jurnal Obsesi : Jurnal Pendidikan Anak Usia Dini, 5(1), 814. https://doi.org/10.31004/obsesi.v5i1.724.

B., S. R., Djumingin, S., \& Munirah. (2021). Efek Media Zoom Cloud Meeting Terhadap Keaktifan dan Hasil Belajar Bahasa Indonesia Siswa di Masa Pandemi Covid-19. Jurnal Kependidikan: Jurnal Hasil Penelitian Dan Kajian Kepustakaan Di Bidang Pendidikan, Pengajaran Dan Pembelajaran, 7(3), 760-766. https://doi.org/10.33394/jk.v7i3.3835.

Brahma, I. A. (2020). Penggunaan Zoom Sebagai Pembelajaran Berbasis Online Dalam Mata Kuliah Sosiologi dan Antropologi Pada Mahasiswa PPKN di STKIP Kusumanegara Jakarta. Aksara: Jurnal Ilmu Pendidikan Nonformal, 6(2), 97. https://doi.org/10.37905/aksara.6.2.97-102.2020.

Bressington, D. T., Wong, W. kit, Lam, K. K. C., \& Chien, W. T. (2018). Concept mapping to promote meaningful learning, help relate theory to practice and improve learning self-efficacy in Asian mental health nursing students: A mixed-methods pilot study. Nurse Education Today, 60(February 2017), 47-55. https://doi.org/10.1016/j.nedt.2017.09.019.

Chen, D., Putri, N. D., Meliza, W., Astuti, Y., Wicaksono, L. Y., \& Putri, W. A. (2020). Identifikasi Minat Siswa SMA Kelas X Terhadap Mata Pelajaran Fisika. PENDIPA Journal of Science Education, 5(1), 36-39. https://doi.org/10.33369/pendipa.5.1.36-39.

Essgaer, M., \& Nasir, I. (2021). Evaluation of using Google Classroom as a Tool for Asynchronous E-learning at Sebha University Evaluation of using Google Classroom as a Tool for Asynchronous E-learning at Sebha 
University. Sebha University Journal of Pure \& Applied Sciences, 20 NO. 1(February), 44-49. https://doi.org/10.51984/jopas.v20i1.986.

Fitriani, I. N., Al-Ghozali, M. D. H., \& Ashoumi, H. (2019). Efektivitas Metode Pembelajaran Snowball Throwing Pada Mata Pelajaran Al-Qur'an Hadist Untuk Meningkatkan Minat Belajar Siswa Kelas XI di MAN 1 Jombang. At-Tuhfah: Jurnal Studi Keislaman, https://journal.unnes.ac.id/nju/index.php/JPTM/article/download/9143/5957.

Fiyanti, O., Rahmawati, N. K., \& Wulandari, A. (2020). Perbedaan Hasil Belajar Matematika Peserta Didik dengan Pembelajaran E-Learning Berbantuan Aplikasi Zoom dan Google Classroom. Prosiding Seminar Nasional Pendidikan STKIP Kusuma Negara II, Abstrak Pe, 132-138. scholar.google.co.id/citations?user=UOy4fdIAAAAJ\&hl=id.

Handayani, D., Nurhayati, N., \& Herawati, H. (2020). Hubungan Antara Minat Belajar Siswa Dan Motivasi Belajar Terhadap Hasil Belajar Bahasa Inggris Siswa Kelas V Sd Negeri Cibuluh 6 Kota Bogor. Jurnal Teknologi Pendidikan, 9(1). https://doi.org/10.32832/tek.pend.v9i1.2710.

Haqien, D., \& Rahman, A. A. (2020). Pemanfaatan Zoom Meeting untuk Proses Pembelajaran pada Masa Pandemi Covid-19. SAP (Susunan Artikel Pendidikan), 5(1). https://doi.org/10.30998/sap.v5i1.6511.

Ismawati, D., \& Prasetyo, I. (2020). Efektivitas Pembelajaran Menggunakan Video Zoom Cloud Meeting pada Anak Usia Dini Era Pandemi Covid-19. Jurnal Obsesi : Jurnal Pendidikan Anak Usia Dini, 5(1), 665. https://doi.org/10.31004/obsesi.v5i1.671.

Jupriyanto. (2018). Kemampuan Berpikir Kritis Siswa Dalam Pembelajaran Ilmu Pengetahuan Alam Kelas Iv. Jurnal Ilmiah Pendidikan Dasar, 5(2), 105. https://doi.org/10.30659/pendas.5.2.105-111.

Karollina, N., Hidayati, U., \& Syaflita, D. (2021). Penggunaan Aplikasi Google Classroom Dan Google Form Pada Pembelajaran Ipa Di Mts Darul Hikmah Pekanbaru. Riau Education Journal, 1(1), 21-27. https://jurnal.pgririau.or.id/index.php/rej/article/view/8.

Khodijah, S. S., \& Setiawan, W. (2020). Analisis Minat Belajar Matematika Siswa Smp Kelas Ix Pada Materi Grafik Fungsi Kuadrat Berbantuan Software Geogebra. Journal of Honai Math, 3(1), 27-40. https://doi.org/10.30862/jhm.v3i1.112.

Kostiainen, E., Ukskoski, T., Ruohotie-Lyhty, M., Kauppinen, M., Kainulainen, J., \& Mäkinen, T. (2018). Meaningful learning in teacher education. Teaching and Teacher Education, 71, 66-77. https://doi.org/10.1016/j.tate.2017.12.009.

Lisma, E., Rahmadhani, R., \& Siregar, M. A. P. (2019). Pengaruh Kecemasan Terhadap Minat Belajar Matematika Siswa. ENLIGHTEN (Jurnal Bimbingan Dan Konseling Islam), 2(2), 85-91. https://doi.org/10.32505/enlighten.v2i2.1345.

Listyarini, D. W., As'ari, A. R., \& Furaidah. (2018). Pengaruh Model Teams Games Tournament Berbantuan Permainan Halma terhadap Minat dan Hasil Belajar pada Materi Bunyi Siswa Kelas IV Sekolah Dasar. Jurnal Pendidikan: Teori, Penelitian, Dan Pengembangan, 3(5), 538-543. http://dx.doi.org/10.17977/jptpp.v3i5.10930.

Maharani, N., \& Kartini, K. S. (2019). Penggunaan google classroom sebagai pengembangan kelas virtual dalam keterampilan pemecahan masalah topik kinematika pada mahasiswa jurusan sistem komputer. PENDIPA Journal of Science Education, 3(3), 167-173. https://doi.org/10.33369/pendipa.3.3.167-173.

Mayasari, F., Dwita, D., Jupendri, J., Jayus, J., Nazhifah, N., Hanafi, K., \& Putra, N. M. (2019). Pelatihan Komunikasi Efektif Media Pembelajaran Google Classroom Bagi Guru Man 2 Model Pekanbaru. Jurnal Pengabdian UntukMu NegeRI, 3(1), 18-23. https://doi.org/10.37859/jpumri.v3i1.1155.

Mubarak, M. R., Wahdah, N., Ilmiani, A. M., \& Hamidah, H. (2020). Zoom Cloud Meeting: Media Alternatif dalam Pembelajaran Maharah Kalam di Tengah Wabah Virus Corona (Covid-19). Arabiyatuna: Jurnal Bahasa Arab, 4(2), 211. https://doi.org/10.29240/jba.v4i2.1445.

Nasution, R. H., Hapidin, H., \& Fridani, L. (2020). Pengaruh Pembelajaran ICT dan Minat Belajar terhadap Kesiapan Membaca Anak Usia Dini. Jurnal Obsesi: Jurnal Pendidikan Anak Usia Dini, 4(2), 733. https://doi.org/10.31004/obsesi.v4i2.411.

Nirfayanti, N., \& Nurbaeti, N. (2019). Pengaruh Media Pembelajaran Google Classroom Dalam Pembelajaran Analisis Real Terhadap Motivasi Belajar Mahasiswa. Proximal Jurnal Penelitian Matematika Dan Pendidikan Matematika, 2(1), 50-59. https://e-journal.my.id/proximal/article/view/211.

Nurfadilla, \& Rosleny. (2018). Hubungan Minat Baca Dengan Prestasi Belajar Ips Siswa Kelas V SD Gugus III Seyegan. Jurnal Kajian Pendidikan $\quad$ Dasar, $3(1), \quad 43-450$. http://journal.unismuh.ac.id/index.php/jkpd/article/download/1173/1071.

Nurfalah, E. (2019). Optimalisasi E-Learning berbasis Virtual Class dengan Google Classroom sebagai Media Pembelajaran Fisika. Physics Education Research Journal, 1(1), 46. https://doi.org/10.21580/perj.2019.1.1.3977.

Pambudi, B. A. (2018). Hubungan Penggunaan Jaringan Internet, Pelayanan Administratif, Minat Dan Motivasi Belajar Dengan Prestasi Mahasiswa. Jurnal Manajemen Dan Supervisi Pendidikan, 2(3), 159-168. https://doi.org/10.17977/um025v2i32018p159. 
Permata, A., \& Bhakti, Y. B. (2020). Keefektifan Virtual Class dengan Google Classroom dalam Pembelajaran Fisika Dimasa Pandemi Covid-19. JIPFRI (Jurnal Inovasi Pendidikan Fisika Dan Riset Ilmiah), 4(1), $27-33$. https://doi.org/10.30599/jipfri.v4i1.669.

Qholby, W., \& Lazulva. (2020). Pengaruh Penerapan Project Based Learning Melalui Google Classroom Terhadap Hasil Belajar Siswa Pada Materi Laju Reaksi. Journal of Research and Education Chemistry, $2(1), 23$. https://doi.org/10.25299/jrec.2020.vol2(1).4863.

Rofiqah, T., \& Sunaini, S. (2017). Hubungan Antara Minat Belajar Dengan Hasil Belajar Pada Siswa Kelas X Sma Integral Hidayatulah Batam. KOPASTA: Jurnal Program Studi Bimbingan Konseling, 4(1), 41-46. https://doi.org/10.33373/kop.v4i1.1122.

Rozikin, S., Amir, H., \& Rohiat, S. (2018). Hubungan Minat Belajar Siswa dengan Prestasi Belajar Siswa pada Mata Pelajaran Kimia di SMA Negeri 1 Tebat Karai dan SMA Negeri 1 Kabupaten Kepahiang. Jurnal Pendidikan Dan Ilmu Kimia, 2(1), 78-81. https://doi.org/10.33369/atp.v2i1.4740.

Rut, N., Gaol, R. L., Abi, A. R., \& Silaban, P. J. (2020). Pengaruh Permainan Tradisional Terhadap Keterampilan Sosial Anak Kelas Iv SD 091526. Jurnal Education FKIP UNMA, 6(2), 449-455. https://doi.org/10.31949/educatio.v6i2.568.

Sheelavant, S. (2020). Google classroom - An effective tool for online teaching and learning in this COVID era. Indian Journal of Forensic Medicine and Toxicology, 14(4), 494-500. https://doi.org/10.37506/ijfmt.v14i4.11527.

Sirajuddin. (2018). Pengaruh Model Pembelajaran Kooperatif Dan Minat Belajar Siswa Terhadap Hasil Belajar Sejarah. Jurnal Ekonomi Efektif, 1(1), 64-83. https://doi.org/10.32493/JEE.v1i1.1982.

Soni, Hafid, A., Hayami, R., Fatma, Y., Wenando, F. A., Amien, J. Al, Fuad, E., Unik, M., Mukhtar, H., \& Hasanuddin. (2018). Optimalisasi Pemanfaatan Google Classroom Sebagai Media Pembelajaran Di SMK Negeri 1 Bangkinang. Jurnal Pengabdian Untuk Mu NegeRI, 2(1), 1-4. https://doi.org/10.37859/jpumri.v2i1.361.

Sugiyono. (2011). Metode Penelitian Tindakan Pendekatan R \& D. Alfabeta.

Sulistyawati, E. (2020). Keefektifan pendekatan kontekstual berbasis budaya lokal ditinjau dari prestasi, minat belajar, dan apresiasi terhadap matematika. JP3M (Jurnal Penelitian Pendidikan Dan Pengajaran Matematika), 6(1), 27-42. https://doi.org/10.37058/jp3m.v6i1.1421.

Sutrisna, D. (2018). Meningkatkan Kemampuan Literasi Mahasiswa Menggunakan Google Classroom. FON: Jurnal Pendidikan Bahasa Dan Sastra Indonesia, 13(2), 69-78. https://doi.org/10.25134/fjpbsi.v13i2.1544.

Tamardiyah, N. D. (2017). Minat Kedisiplinan dan Ketekunan Belajar terhadap Motivasi Berprestasi dan Dampaknya pada Hasil Belajar Matematika SMP. Manajemen Pendidikan, 12(1), 26. https://doi.org/10.23917/jmp.v12i1.2972.

Wardani, N. M. A., Suniasih, N. W., \& Sujana, N. W. (2019). Korelasi Antara Konsep Diri dengan Kemampuan Pemecahan Masalah IPS. Jurnal Ilmiah Sekolah Dasar, 2(2), 209-216. https://doi.org/10.23887/tscj.v2i1.18382.

Yuliar, A. D. (2019). Upaya Meningkatkan Minat Belajar Matematika Melalui Media Pembelajaran Berbantuan Komputer. Desimal: Jurnal Matematika, 2(3), 211-231. https://doi.org/10.24042/djm.v2i3.4830.

Yunitasari, R., \& Hanifah, U. (2020). Pengaruh Pembelajaran Daring terhadap Minat Belajar Siswa pada Masa COVID 19. Edukatif: Jurnal Ilmu Pendidikan, 2(3), 236-240. https://doi.org/10.31004/edukatif.v2i3.142.

Zahrawati, F., \& Aras, A. (2020). Pembelajaran Berbasis Riset dengan Memanfaatkan Google Classroom pada Mahasiswa Tadris Ilmu Pengetahuan Sosial. Jurnal Ilmiah Iqra', 14(2), 143-154. https://doi.org/10.30984/jii.v14i2.1253. 